Rocznik Komparatystyczny - Comparative Yearbook

12 (2021): 225-240

DOI: 10.18276/rk.2021.12-09

ISSN (print): 2081-8718 | ISSN (online): 2353-2831

(c) (1) ()

Olga Szadkowska-Mańkowska

Uniwersytet Warszawski

ORCID: 0000-0002-4873-9811

\title{
In Search of Collective Identity. The Formation of National Consciousness in Julian Ursyn Niemcewicz's Travels Abroad
}

The motif of searching for identity in journeys is one of the most often recurring narrative elements. The attractiveness of diaries encourages tracking the way a traveller reacts to a different reality. An intriguing theme is the search for a collective identity - the journey becomes the space where national history is turned into an individual's history. One of the most underrated Polish travellers, Julian Ursyn Niemcewicz, embarked on an interesting journey at the end of the $18^{\text {th }}$ century, from Russia through America to Paris. Although he did not gain international fame, he still remains one of the pioneering figures writing about democracy and the role of an individual in the international course of history. Called one of the first Polish romantics, while at the same time strongly rooted in the age of Enlightenment, he is undoubtedly an interesting example of a link between the epochs. Niemcewicz's Enlightenment persona was just as incoherent and internally diverse as the final years of the $18^{\text {th }}$ century in Poland. As Niemcewicz expressed it himself, his innate inclination led him to the literary activity in which he was engaged throughout his life and formed a bridge between the cultural revival of the last decades of independent Poland and the post-partition period. He wanted to "transmit to future generations that love of country, that courage for which the Pole had once been renowned and had 
acquired the country and fame that it has now lost" (Krzyżanowski: 5). It was Niemcewicz's conviction that the knowledge of history can be, for a person, a country-binding experience. On the one hand, his ballad called Duma gave rise to the famous author of Ballads and Romance and prophet of the Polish Romanticism era, Adam Mickiewicz; on the other hand, Niemcewicz's youthful years were marked by a fascination with the ideas and forms of Enlightenment intellectualism. However, it is worth emphasising that the dominant idea in Niemcewicz's life was to serve his country.

Could Niemcewicz have provided valuable information about the mechanisms of the revolution, varieties of political forms, and about the emergence of a new post-Enlightenment order in Europe like Tocqueville and Marquis de Custine? As Włodzimierz Bolecki argues, he could have, though he did not, which has made him a forgotten "school poet" of the Polish Enlightenment (Bolecki: 408). Niemcewicz did not take advantage of this opportunity. Whether this was because of his old age or deep experiences related to Poles' permanent loss of independence will remain open to research. However, his innovation should be forcefully emphasised, not only when observing political and social life understood as a collective, but also in the way of looking at the individual entangled in the wheels of history.

His stay in America, so strongly emphasised in Polish historical and literary research, allowed Niemcewicz to formulate the idea that the fate and character of nations depend on the political system and that the measure of the civilisational development of states is the scope of freedom that an individual can exercise. He watched the Americans and the English, seeing there not only equality, happiness and freedom, ${ }^{1}$ but also the energy that flowed through the nations. And finally, he looked at Italy and observed a situation similar to Poland - he perceived these lands as a living map of a lost civilisation and as a national cemetery in areas defeated by despotism and tyranny.

Due to the lack of knowledge of his most interesting works which are either underrated or unpopular, he is reduced to the role of the author of Historical

\footnotetext{
1 Niemcewicz is considered one of the pioneers of knowledge about the United States, to whom we owe the first detailed descriptions of everyday life in America at the turn of the $18^{\text {th }}$ and $19^{\text {th }}$ centuries, as well as extremely interesting in terms of his political observation correspondence with Jefferson (Drozdrowski; Pastusiak; Krzyżanowski; Sidwa, Coleman).
} 
Songs and the Return of a Deputy. This article aims to put Niemcewicz in a different light. It must be forcefully stated that it is worth looking at the uniqueness of Niemcewicz's journey to Italy, understood as searching for ways to regain the lost identity - which has always been one of the most important and longest-lasting literary motifs.

The form of literary travel seems to be the most interesting research area in this case. First, because it was travels that encompassed the whole world, the entire political cosmos, which Niemcewicz observed and from which he learned for future generations - or as a bittersweet consolation for himself. In addition, records of Niemcewicz's travels over many years, not only in Europe, are a real testimony to his interpersonal meetings. And these are related to the most interesting reflections on the identity of a man of the late $18^{\text {th }}$ century.

\section{Niemcewicz abroad}

Before the author proceeds to Niemcewicz's presence in Italy, it is worth remembering why he remains such an important figure, not only for the Polish but also for the European Enlightenment. A man of two worlds, two epochs, an ark of the covenant between the elder and the younger years, he occupies a unique position in the annals of Poland's culture and its relationship with the West. The relationship between Niemcewicz and European culture should be viewed from a dual perspective. The first rationale for Niemcewicz's international perspective was his full commitment to European and American affairs. This was confirmed by the records of numerous journeys and permanent stays, among others, in the United States, England, France and Italy. In turn, the second perspective is the reception of Niemcewicz abroad, starting in the early $19^{\text {th }}$ century and lasting until the 1960 s.

Let us first consider Niemcewicz through the prism of his foreign journeys and the substantial role these played in his reflections on political and social identities. He learned about English culture and language very well, firstly in 1783-1785, then in 1787-1788. England made a huge impression on him, he admired the country and its people, the arrangement of apartments, the care for order, the cultivation of fields and gardens. In the Memoirs of My Times, he wrote: "I have seen in this country all the blessings of reasonable freedom, pure 
morality, and Enlightenment religion. I abandoned it with regret" (Niemcewicz, 1957, vol. 1: 233). Almost ten years later, in 1796, he visited England again on a trip from Petersburg to Philadelphia. Then began the period of several years when Niemcewicz stayed in the other hemisphere. Niemcewicz arrived in the United States in 1797. His impressions of the eventful years that followed, his description of this land, its habits and of the fascinating people he met there are not only one of the first Polish descriptions of America, but also cast an interesting light upon the early years of the United States. He was a very attentive observer of both social and political life abroad, and his memoirs from that time are filled with reflections on the identity of a man and the role of individuals in a society. Niemcewicz had the opportunity to visit the concluding session of the Pennsylvania State Legislature in Philadelphia. He was particularly impressed by the fact that the assembly was unspoiled by the luxuries which could be theirs. Equally impressive to him was the absence of swords at the meeting, contrary to other legislatures of which sessions often provided the opportunity for violence, as was the case in Poland. He also considered the degree of equality which existed among the various ranks of American society, the law being applied in the same manner to all, worthy of note (Krzyżanowski: 59). His state of mind at the time was reflected in his memoirs:

Where to go, what should I live from? I walked the streets of Philadelphia for a long time. How I regretted then that instead of literature I did not have any craft or talent in beautiful arts. I could easily earn money by having them! Ah! how beneficial advice gave people J.J. Rousseau, when he advised them that their children should teach the craft. They didn't listen! In Poland, in particular, this thought was considered a dishonour of nobility.

(Niemcewicz, 1957, vol. 2: 225)

Staying in the United States until 1802, and then again from 1804 to 1807, he obtained American citizenship and lived the life of a "gentleman farmer" for several years. After receiving information about the creation of the Duchy of Warsaw in May 1807, he left America. What distinguishes Niemcewicz from other Polish writers travelling to America or England is his cordial, but also uncompromising, way of writing about man's obligation to freedom. Niemcewicz felt a citizen of enslaved Poland, felt a citizen of Europe, felt a citizen of the United States. In the uncertain times depriving Polish citizens 
of their identity, he gained confidence in his identity - as a spiritually free man. He valued this the most in Americans; the American state was for Niemcewicz an example of a fully independent state in which real freedom ruled. He asked which nation "on the whole earth may be called independent? They oppress them all, that is, home shackles, or foreign ties; from Tiber to the Volga people moan in chains" (Niemcewicz, 1959: 180). Let the role he played abroad be demonstrated by the fact that when he was laid to rest in the cemetery of Montmorency, a large group of Polish, French, American and English residents of Paris united to pay him a last tribute (Krzyżanowski: 70). Niemcewicz's definite merit lies in establishing an enduring cultural and intellectual link not only between Poland and America, but also Poland and Europe. It has been evoked in his appeal to the international political and cultural elite.

Another important point to consider is the issue of the reception of Niemcewicz's work abroad. Significant already in the $19^{\text {th }}$ century, it had a renaissance in the 1960s. It should be noted that Niemcewicz's work was translated into several other languages. His lyrics can be found in English, French, German, Czech, Russian and Dutch. ${ }^{2}$ All this refers to Niemcewicz's

2 Duma o Żótkiewskim (1786) was translated into Czech and German in the first half of the $19^{\text {th }}$ century (Zolkiewski's Helm. Morgenblatt 1822, no 180 and V.S. Stulc. Kvety ceske 1834, no. 45, 379-380.) Duma o Stefanie Potockim (1788) was translated into Czech and English: J.P. Koubek, "Ceska vcela” (1834), J.B. Pichl, "Casopis Ceskeho Musea” (1852, vol. 4, 115), J. Bowring, "London Magazine" (1826, vol. 19, 267-270). P. Sobolewski: Poets and Poetry of Poland (Chicago, 1881). Into Russian were translated, i.a.: K.F. Rylejew: Glinski, "Soriewnowatiel" 1822 (no. 9, 314-321) and in the $20^{\text {th }}$ century, W. Arcimowicz, Kusziwn i czaszka, "Slawianie" (1957). To the famous French translations belongs La vieille Pologne. Album historique et poetique, compose de chants et legendes (Paris, 1833) and Boyer-Nioche: Fables choises, La Pologne Litterarie (Paris, 1839). Translations into Dutch were also carried out in the $19^{\text {th }}$ century: Lejbus $i$ Sióra. Romans żydowski (1820) was translated into German in 1825: Levi en Sara. Eene Joodsche familie geschiedenis in Polen (Amsterdam, 1825) and Jan z Tęczyna. Powieść historyczna (1823), Johan Tenczynski. Een verhaal uit de geschiedenis van Polen (vol. 1-2, Amsterdam 1829). As indicated before, Niemcewicz's works had already been translated into English in the 1820s - not only the already mentioned Duma o Stefanie Potockim, but Glinski was also translated by John Bowring in the "London Magazine" (Vol. 19, Oct. 1827) and reprinted in Specimens of the Polish Poets (London, 1827) (Sidawa, Coleman: 14-15). The most significant editions and publications in English in the $19^{\text {th }}$ and $20^{\text {th }}$ centuries include, among others: Kościuszko, a eulogy delivered Nov. 14, 1817, tr., anon as "Kosciusco", in H. Niles, Principles and Acts of the Revolution in America (Baltimore, 1822: 474-57); Copernicus, portion of an eulogy delivered by Niemcewicz, May 11, 1830, on the 
significant presence in the international literary arena. He was willingly translated into many languages, as evidenced by numerous reprints. He was an author vitally rooted in European culture of the second half of the $19^{\text {th }}$ century - but also in the $20^{\text {th }}$ century, where his constant presence can be seen. In the light of the sources extracted, Niemcewicz does not seem to be such a foreign poet to international readers. From the research conducted, Niemcewicz turns out to be a figure who does not occupy an unequivocal place in foreign cultural space. His reception, presence or absence, depending on the historical period, political situation, literary trends, was changing, making him alternately a primary, secondary and sometimes ignored person. By tracing the translations, one can capture the dynamics of their reception in the West. There was a kind of sinusoid of interest in his works, which additionally presents the individual phases of his reception and the attitude of international works and journals towards Niemcewicz's artistic heritage. At the end of the $19^{\text {th }}$ century, he was considered as a Polish author who was worth reading, worth knowing, and whose translations appeared in foreign press and in materials commemorating the achievements of Polish enlighteners.

\section{The Polish poet meets an Italian revolutionary}

Although the relationship between Niemcewicz and Americans is extremely interesting (not only because of Niemcewicz's pioneering diary role in Poland, but also because of its international resonance), there is one much more absorbing question, which has not been researched. Travels to Italy in the second half of the $18^{\text {th }}$ century were highly popular (Brahmer; Loret; Barycz; Sajkowski; Burkot; Chachaj; Kowalczyk; Tygielski; Płaszczewska 2003; Płaszczewska, 2010; Widłak), nevertheless the aspect of Niemcewicz's attitude towards Italian culture has remained incomprehensible. And yet, when talking about a strong connection between individuals and communities, which is not always harmonious, or even overpowering, there was no better figure that could be

occasion of the unveiling of the Thorvaldsen Monument, "Foreign Quarterly Review" (vol. 8, April, 1831: 554); Description of the flight of Prince Adam Czartoryski, and of his subsequent life in London, "Poland", by William R. Morfill, (New York, 1893: 260). 
a patron of this agon, than the Italian Enlightenment playwright, Vittorio Alfieri. Strongly connected with the Polish theatre scene in the $19^{\text {th }}$ and $18^{\text {th }}$ centuries, his revolutionary slogan about the identity of people had already encountered a warm reception in Poland - precisely through Julian Ursyn Niemcewicz. It is worth following the trail of Niemcewicz's Italian peregrinations to make his international attitude more complete.

It might be tempting to answer the question about the status of the Polish perception of Venice or Rome in the late $18^{\text {th }}$ century, but also what were the role, privileges, and responsibilities of the individual undertaking this polemic or, better say, an Italian journey, as in the case of Julian Ursyn Niemcewicz. He travelled to Italy twice - first in 1783-84, when he visited, inter alia, Venice, Rome, Naples, and ended his journey in Sicily; and the second time in the 1790s, when the focal point of his visit was Florence - there he met a poet, extremely involved in the Italian national affairs, Vittorio Alfieri. I will return to these considerations later in the article. When Niemcewicz arrived in Italy for the first time, he was only 27 years old. His memoirs contain youthful and valuable insights. They characterise his socio-political commitment and awareness of the changes which had been taking place in Europe at the end of the $18^{\text {th }}$ century. Unfortunately, the fruit of his Italian stay in 1783-84 was lost in 1812. We do not currently have a copy of the Italian diary from that time. The records he wrote down in Memoirs of my time are extremely interesting; however, it should be remembered that he wrote this at the end of his life (the origin of the memoirs is estimated for the years 1823-38), as a man of over 70, whose report was much less precise than the missing Italian diary.

The whole report of the stay in Italy was characterised by great sensitivity and admiration for the enormity of Italian beauty. Niemcewicz was captivated by the beauty of the landscape and the architectural treasures. It is interesting that, from the very beginning, Niemcewicz's narrative demonstrated the characteristics of sentimental and even romantic sensitivity, revealing the author's strong propensity for reflection and admiration for the charm and majesty of nature. On his way to Bologna, Niemcewicz crossed the Apennines and was captivated by the picturesque mountains and the feeling of freedom at the sight of clouds flowing at his feet. He also followed the path of his ancestors' memorabilia. In Padua, he noted the traces of studies of numerous Poles, preserved over the 
centuries in the university certificate. The collections of museum curiosities in Bologna revealed before him the gift from Stefan Batory to the Pope in the form of a lynx. He described the memorabilia of his countrymen with nostalgia and the feeling of being a participant in the relay race of generations.

All this made his trip a typical Italian journey of a Polish artist during the Grand Tour. Nevertheless, in the fragments about Italy, there was another aspect, which has not been much discussed until now, and was associated with his "moral dictatorship" (as Prince Adam Czartoryski called it) and, at the same time, with being an "idol of human hearts" (as Krystyn Lach Szyrma spoke about Niemcewicz). What distinguished Niemcewicz's record compared to others from their Italian journeys was the constant and uncompromising interest in social, political, and independence issues. He was the one who took after Mickiewicz, saying "not this nation is great, which sees its borders on the map, but this nation, which preserves the national spirit, customs, and bravery."

This was perfectly illustrated by his observations of Italian cities. Niemcewicz was everywhere, he saw a lot and was interested in everything. Venice showed him the reality of a city with a long-lasting merchant and political tradition. He saw a pompous wedding ceremony at sea, which was presided over by the doge, and later a wonderful party decorated with illuminations. He knew exactly where this glamour came from; he treated these external manifestations of strength and glory as the remnants of the splendid republic. He saw, however, that this city was only a reflection of its old power, and that for the fall of Venice were responsible: the oligarch government, suspicious despotism at home, fear, indifference to external events, the destruction of old courage and boldness. What caused this fall, according to Niemcewicz? The reasons he found were characterised by the accuracy of his observations and reflections on the transitoriness of the powers, both Venetian and Polish:

I found the former government, old forms, old customs, but power has disappeared. The Senate, busier with stopping unlimited power, than with protecting Venice from the strength of its neighbours, neglected its income, naval and earth forces $[\ldots]$. Equal fate, we are sharing with the Venetians, with this the heaviest.

(Niemcewicz, 1957, vol. 1: 175-176) 
In turn, the view of the ancient ruins and the great wealth of works of art modelled on ancient statues and sculptures caused Niemcewicz's sad reflection on the poverty of Polish artistic collections, ravaged and looted as a result of numerous wars, organised and systematic robberies and confiscations committed by external invaders, who for centuries harassed Rzeczpospolita, depleting its cultural heritage. In Sicily, in turn, he wrote:

Night dipped me into dreary thoughts. The winged thought, moving me into the ancient and present ages of Sicily, put her old pride, glory and power next to today's misery and wickedness. What is this island today? Where are these overpowering republics, where are these towns [...]? Where are these great men, who have glorified this land? They will tell you that time and invasions have torn down everything; but how long ago invasions and wars ceased, how long ago the peace of calm prevails. [...] The answer is easy: with freedom everything blossomed and bloomed, everything collapsed with the arbitrary and feudal government.

(Niemcewicz, 1957, vol. 1: 202)

With his propension to historical reflection, Niemcewicz was a kind of "living memorabilia" for readers; his impact on future generations and the way for younger travellers was enormous. He was not only the traveller who wanted to see everything, but he was also a publicist, soldier, politician, diplomat and, finally, a poet. He was one of the men whose lives would be very strongly influenced by the whole history of the nation as well as by the history of culture. In his political and literary views, he embodied what was seen as the most noble of Polish identity features; he remembered independent Poland and personified its legacy. Yet, at the same time, in his aspirations and tendencies, he sensed modern Poland.

Nevertheless, the relationship of Niemcewicz with the public was best presented in the description of his meeting with the eminent poet Vittorio Alfieri. Indeed, none of the Italian poets of the $18^{\text {th }}$ century was as connected with nationality issues as Alfieri. It must be said that Alfieri's presence in Polish cultural space was as significant as it has been forgotten. Even though he seems absent now, works in literary criticism have continued to prove that he is constantly being discovered anew. Alfieri's reception has not yet been discussed in monograph form, though one should mention the major researchers who have 
contributed to his vivid reception in Poland. ${ }^{3}$ This great tragic "father of the Italian drama", the spiritual patron of the Italian Risorgimento was treated by Niemcewicz as an unusual individual, a deeply unhappy man, a seeker, a passionate lover, and an explosive personality. In chapter eight of Memoirs of my time, Niemcewicz wrote about Alfieri, recalling his journey from Vienna to Florence. Moreover, these memoirs constitute a valuable source for understanding the way of life of the entire age. The author, putting his memories in the form of a biography, reported all political events in Poland in detail. Therefore, it should be no surprise that in the extensive passage about Alfieri, Niemcewicz touched upon the issue of the playwright's political involvement and emphasised the importance of freedom and liberation from all tyranny (both the autocracy and the bloody dominion of the majority). He identified Alfieri's appearance with a great spirit. It is difficult to resist the conclusion that Niemcewicz presented here not even the person of Alfieri or the impression of meeting him, but the whole "Alfieri figure":

Alfieri was handsome, tall, with a face which signifies great soul, he was pale, with eyes of blue, light hair, he explained with the conciseness and strength that we see in his rhymes. He was an ardent prudent freedom defender, his soul was outraged at the bloody fury of the French, as staining and disastrous for the cause of humiliated humanity [...]. I saw the author himself, in a tailcoat with a mantle only thrown over his shoulder, playing the role of Brutus; Alfieri's power and declamation covered the corruption of illusion through sometimes contradictory outfits.

(Niemcewicz, 1957, vol. 2: 62-63)

In this paragraph, Niemcewicz refers to various areas concerning Alfieri: on the one hand, he describes his friends and family arrangements, his character, appearance and behaviour, and on the other, his political beliefs. This meeting is also worth noting due to the cultural phenomenon of literary salons and their significance as institutions of private and public culture in the $18^{\text {th }}$ and $19^{\text {th }}$ centuries. The whole scene took place in the salon of the countess of d'Albany in Florence. It must be mentioned that Niemcewicz knew the story of Alfieri and d'Albany. In 1777, Alfieri met Luisa, fell madly in love with her and, in

${ }^{3}$ I have included more information in the article published last year (Szadkowska-Mańkowska; see also: Karwacka-Pastor). 
1780, helped her to escape from her home-made hell (she was the wife of Karol Edward Stuart, great grandson of Jan III). The countess took refuge in Rome, and after being separated for four years, she later reunited with Alfieri in France. Frightened by the progress of the revolution, although the poet always preached freedom slogans, they left Paris and, in the autumn of 1793, settled in Florence, where the countess opened a salon. One of its attractions was the amateur shows organised by Alfieri, who liked to act as an actor in his own tragedies.

At that time, ritualised forms of contacts with European writers perceived by contemporary people as "great creators" and authorities have been preserved, both in the field of culture and everyday life. The development of artistic and intellectual life, as well as socio-political life, was at that time the unwritten duty of the national writer - in accordance with the mental tradition of the Enlightenment. One of the forms, which defined the management of a literary salon, was treating it as a variant of high life bustling in the private house of a writer, where the audience entered the meeting of the writer with the lovers of his work. Poets, who ran such salons and invited popular artists (and Alfieri was such at the end of the $18^{\text {th }}$ century) could not only see them, but also talk to them or exchange points of view.

The intellectual interview, as I mentioned, was not only about cultural life, but also about important political matters; hence, the interest of Niemcewicz in the non-artistic activity of Vittorio Alfieri. The Polish poet did not omit the Italian theatre performances. According to him, Alfieri was an eager defender of the independence of individuals, and his sensitive soul could not stand what had happened with the slogans of the French Revolution, how they had been transformed. He considered it as "staining and fatal for the cause of the humiliated humanity". ${ }^{4}$ Alfieri in politics (and also in social life) was a frequently used motif in critical-literary reflection in Poland in both the $19^{\text {th }}$ and $20^{\text {th }}$ centuries. Alfieri's commitment would soon be appreciated by Ludwik Osiński, Wojciech Bogusławski, and Franciszek Wężyk. ${ }^{5}$

\footnotetext{
${ }^{4}$ Alfieri's political opinions are contained in all his tragedies, satires and poems, but they were most emphasised in the treaty against the French, Misogallo (Alfieri).

5 The issue of relationships of artists at the turn of the $18^{\text {th }}$ and $19^{\text {th }}$ centuries (such as Franciszek Wężyk, Alojzy Feliński or Antoni Hoffmann) and romantics (Juliusz Słowacki) with Alfieri is still waiting for a full and detailed discussion, but there are studies that consider
} 
Concurrently, the same features would be considered as defects in the theatrical reviews of Alfieri's plays in Poland. The accusation would first of all be the use of political preferences in tragedies and making "of the great tragedies of passions - political tragedies" (Gazeta Warszawska 1816: 2281-2282). It is worth noting the voice of Niemcewicz in the matter of politicising the figure of the Italian poet. It turned out that the argument concerning the political purport of Alfieri's works tackled by Polish theatre critics in the $19^{\text {th }}$ century appeared due to the memoirs of Niemcewicz, based on his reflection from 1793. The manner in which Niemcewicz wrote about Alfieri distinguishes it from other descriptions of historians of literature. Alfieri was a great creator in Niemcewicz's memoirs; nevertheless, he was always serious, subdued, cloudy, haughty. Literary researchers emphasise the extraordinary temperament of the Italian playwright, nervousness and oversensitivity. Niemcewicz also reached for these attributes, nevertheless, he emphasized his political engagement and strong individual personality. Niemcewicz noticed this and wrote it down not only for future generation of travellers, but also theatre critics. No one before had written about Alfieri in the way in which Niemcewicz did: constituting a kind of heartfelt meeting with an Italian poet - in the salon of Alfieri's lover. Niemcewicz brought to the light the well-known facts that had not yet been sought. His reflections were not only the expression and testimony of the author's personal preferences, but above all, the result of archival research, of many read pieces. Niemcewicz knew Italian, read about Italian literature, and was very conscious of what exactly was happening in the late $18^{\text {th }}$ century Italian and Polish literature. This is why his travelling memoirs are so important in understanding the impact of the individual's actions on future generations' travels to Italy. Niemcewicz's work was not only the canon of travel literature, reaching to the sentimental and "protoromantic" character, revealing the author's strong tendency to reflect and admire the charm and majesty of nature, it was also a strong point in indicating the meaning of a strong individual creator in a difficult political situation.

Niemcewicz's Italy is not only a monument or a pedestal, which is worth looking at from all sides and interpreting its meaning from different perspectives

some threads on the relationship between Alfieri and classics and Alfieri-romantics in Poland (see: Hahn; Kleiner; Ujejski; Ratajczakowa). 
of the history of art, it is also a living organism, which he observed, read a lot about, and devoted the young and the fully mature years of his life. The Italy of the author is a meeting place for people, culture, but also for history because it is evident in his memoirs how much the individual is entangled in time and the relationships that are the result of that time. It is illustrated by the figure of Alfieri. The unprecedented description of Alfieri's extraordinary figure confirms that statement. The pulse of the neoclassical age is expressed in Niemcewicz's profound analysis. Niemcewicz broke and refilled the convention of looking at Polish-Italian relations of the $18^{\text {th }}$ and $19^{\text {th }}$ centuries. His Italy is a nation experiencing a common historical disaster, as well as a colourful country focusing on individuals, yet still connected with the history and the period in which it is located.

\section{Conclusion}

The presented issues regarding the role of the description from Niemcewicz's travels abroad allow the capture of some dependencies. First of all, Niemcewicz appears in this perspective as an international figure with considerable cultural and social significance. Secondly, Niemcewicz's view of Poland from a European perspective was an important voice at the end of the $18^{\text {th }}$ century. Thirdly, although his reflections on the Anglo-Saxon situation are well known and commented on, Niemcewicz's attitude towards Italy and Italians requires to be brought to light. Especially because in the Italian - or actually Italian-Polish - relations one can see the discussion about the obligations of the individual towards society at the turn of the $18^{\text {th }}$ and $19^{\text {th }}$ centuries. In the end, the postulate to continue the attempt to recall the work of Niemcewicz in Europe, which began in the late 1950s, seems strong. Additionally, the intense search for identity as a part of the community, highlighted in Niemcewicz's travels, gives it more weight.

In Niemcewicz's travel writings, the contact with otherness takes shape of an identity experience. The political and cultural situation of foreign countries is often put in parallel with that of Poland. In his portrait of Vittorio Alfieri, Niemcewicz emphasizes the poet's political involvement. This feature 
will become one of the most important elements for the identity of Polish romantic writers.

\section{Works Cited}

Alfieri, Vittorio. Il Misogallo. Prose e rime. London, 1806.

Barycz, Henryk. Spojrzenia w przesztość polsko-wtoską. Wrocław: Zakład Narodowy im. Ossolińskich, 1965.

Bibliografia literatury polskiej, „Nowy Korbut”. Vol. 5: Oświecenie: hasta osobowe I-O. Eds. Elżbieta Aleksandrowska, Tadeusz Mikulski. Warszawa: PIW, 196.

Bolecki, Włodzimierz. „Julian Ursyn Niemcewicz (1758-1841)”. Pisarze Polskiego Oświecenia. Vol. 2. Eds. Teresa Kostkiewiczowa, Zbigniew Goliński. Warszawa: PWN, 1994. 387-423.

Brahmer, Mieczysław. Wtochy $w$ literaturze francuskiej okresu romantycznego. Kraków: Polska Akademia Umiejętności, 1930.

Burkot, Stanisław. Polskie podróżopisarstwo romantyczne. Warszawa: PWN, 1988.

Chachaj, Marian. Związi kulturalne Sieny i Polski do końca XVIII wieku. Staropolscy studenci i podróżnicy w Sienie. Sieńczycy i ich dzieta w Polsce. Lublin: Wydawnictwo Uniwersytetu Marii Curie-Skłodowskiej, 1998.

Croce, Benedetto. Poesia e non poesia; note sulle letteratura europea del secolo decimonono. Bari: G. Laterza, 1923.

Drozdrowski, Marian Marek. „Recepcja rewolucji i cywilizacji amerykańskiej w twórczości Juliana Ursyna Niemcewicza”. Kultura i spoteczeństwo 4 (1976): 53-74.

Hahn, Wiktor. „Przyczynek do genezy Marii Stuart Słowackiego”. Ateneum 19.1 (1984): 260-296.

Karwacka-Pastor, Dorota. Cztowiek i wtadza: o twórczości Vittorio Alfieriego. Gdańsk: Wydawnictwo Uniwersytetu Gdańskiego, 2014.

Kleiner, Juliusz. Juliusz Stowacki. Warszawa: Gebethner i Wolff, 1919.

Kowalczyk, Małgorzata Ewa. Obraz Wtoch w polskim piśmiennictwie geograficznym i podróżniczym XVIII wieku. Toruń: Instytut Historyczny Uniwersytetu Wrocławskiego, 2005.

Krzyżanowski, Ludwik, ed. Niemcewicz and America. New York: Polish Institute of Arts and Sciences in America, 1961. 
Loret, Maciej. Życie polskie w Rzymie w XVIII wieku. Roma: Scuola Tipografica Pio X, 1930.

Niemcewicz, Julian Ursyn. Podróże po Ameryce 1797-1807. Ed. Antonina Wellman-Zalewska. Wrocław-Warszawa: Zakład Narodowy im. Ossolińskich, 1959.

Pamiętniki czasów moich. Vol. 1-2. Ed. Jan Dihm. Warszawa: PIW, 1957.

Pastusiak, Longin. Pierwsi polscy podróżnicy w Stanach Zjednoczonych. Warszawa: Krajowa Agencja Wydawnicza, 1980.

Płaszczewska, Olga. Przestrzenie komparatystyki-italianizm. Kraków: Universitas, 2010.

-----. Wizja Wtoch $w$ polskiej i francuskiej literaturze okresu romantyzmu. Kraków: Universitas, 2003.

Ratajczakowa, Dobrochna. „Franciszek Wężyk (1785-1862)”. Pisarze Polskiego Oświecenia. Vol. 3. Eds. Teresa Kostkiewiczowa, Zbigniew Goliński. Warszawa: PWN, 1996. 304-332.

-----. „Antoni Hoffmann (ok. 1760-1816)”. Pisarze Polskiego Oświecenia. Vol. 3. Eds. Teresa Kostkiewiczowa, Zbigniew Goliński. Warszawa: PWN, 1996. 586-609.

Sajkowski, Alojzy. Wtoskie przygody Polaków, wiek XVI-XVIII. Warszawa: Państwowy Instytut Wydawniczy, 1973.

Sidwa, Anna, Marion Coleman. Niemcewicz an Anniversary Tribute. Cambridge Springs, PA: Alliance College, 1958.

Szadkowska-Mańkowska, Olga. "A City Full of Life or a City Buried Alive? Vittorio Alfieri's Venice and Venice in the Travel Journals by Polish Artists at the Turn of the 19th Century". Czytanie Literatury. Eódzkie Studia Literaturoznawcze 9 (2020): 51-63.

Tygielski, Wojciech. W podróży po Europie. Studia z dziejów kultury nowożytnej. Warszawa: Wydawnictwa Uniwersytetu Warszawskiego, 2019.

Ujejski, Józef. „Wstęp”. Antoni Hoffmann. Tragedie. Warszawa: W. Maślankiewicz i F. Jabczyński, 1929. 1-65.

Waśko, Andrzej. Historia wedtug poetów. Myślenie metahistoryczne w literaturze polskiej (1764-1848). Kraków: Arcana, 2015.

Widłak, Stanisław. Italia e Polonia. Popoli e Lingue in Contatto. Kraków: Wydawnictwo Uniwersytetu Jagiellońskiego, 2010. 


\title{
In Search of Collective Identity. The Formation of National Consciousness in Julian Ursyn Niemcewicz's Travels Abroad
}

\begin{abstract}
Summary
This article illustrates the significance of Italian journeys in the context of the $18^{\text {th }}$ century travel literature, underlining the uniqueness of insights found in the "Diaries" of Julian Ursyn Niemcewicz. Over the course of history Italy has been an important destination of many travels. In the $18^{\text {th }}$ century in particular. Using a historical and literary approach, the article showcases how group identity has been utilized in the personal diaries of Niemcewicz and simultaneously explores the question of the influence of an individual on future generations travelling to Italy.
\end{abstract}

Keywords: Italianism, Polish travellers in Europe, travel narratives, Julian Ursyn Niemcewicz, Italian journeys, identity, Polish-Italian literary relations

Słowa kluczowe: italianizm, polscy podróżnicy w Europie, literatura podróżnicza, Julian Ursyn Niemcewicz, włoskie podróże, tożsamość, polsko-włoskie związki literackie

\section{Cytowanie}

Szadkowska-Mańkowska, Olga. „In Search of Collective Identity. The Formation of National Consciousness in Julian Ursyn Niemcewicz's Travels Abroad”. Rocznik Komparatystyczny 12 (2021): 225-240. DOI: 10.18276/rk.2021.12-09. 